\title{
THE PROBLEM OF ARITY IN STOIC LOGIC: THE CASE OF THE DISJUNCTION
}

\section{EL PROBLEMA DE LA ARIDAD EN LA LÓGICA ESTOICA: EL CASO DE LA DISYUNCIÓN ${ }^{1}$}

\author{
Miguel López-Astorga ${ }^{2}$ \\ Instituto de Estudios Humanísticos "Juan Ignacio Molina”, \\ Universidad de Talca (Chile)
}

Recibido: 4-12-2015

Aceptado: 17-6-2016

\begin{abstract}
Both ancient sources and contemporary authors seem to agree, in general, that the Stoic disjunction was exclusive. The problem is that some ancient sources inform that the Stoics also considered disjunctions with more than two disjuncts and stated that such disjunctions were true if only one of their disjuncts was true as well. This appears to be a logical mistake, since an exclusive disjunction with three disjuncts can be true if its three disjuncts are true too. However, in this paper, I analyze this problem based on the mental models theory, and try to show that, under criteria different from those of standard logic, it is possible to claim that, in an exclusive disjunction with more than two disjuncts, only one disjunct can be true.
\end{abstract}

Keywords: arity; disjunction; mental models; standard logic; Stoic logic

Resumen: Tanto las fuentes antiguas como los autores contemporáneos parecen estar de acuerdo, en general, en que la disyunción estoica era exclusiva. El problema es que algunas de las fuentes antiguas nos informan que los estoicos

1. Acknowledgments: This paper is a partial result of the Project N. I003011, "Algoritmos adaptativos e inferencias lógicas con enunciados condicionales", supported by the Directorate for Research of the University of Talca (Dirección de Investigación de la Universidad de Talca), Chile. The author is also the main researcher of that Project.

2. (milopez@utalca.cl) Doctor en Lógica y Filosofía de la Ciencia por la Universidad de Cádiz (España). Grado de Doctor reconocido por la Universidad de Chile. Licenciado en Filosofía y Ciencias de la Educación (sección Filosofía) por la Universidad de Sevilla (España). Profesor de Educación Media en Filosofía por la Universidad de Chile (obtenido por revalidación). En la actualidad, es académico del Instituto de Estudios Humanísticos "Juan Ignacio Molina" de la Universidad de Talca (Chile) y Director de la revista Universum, editada por dicho instituto. 
también consideraron disyunciones con más de dos términos y que afirmaron que tales disyunciones eran verdaderas si solo uno de sus términos era igualmente verdadero. Esto parece ser un error lógico, pues una disyunción exclusiva con tres términos puede ser verdadera si sus tres términos son también verdaderos. No obstante, en este trabajo, analizo el problema basándome en la teoría de los modelos mentales y trato de mostrar que, atendiendo a criterios diferentes a los de la lógica estándar, es posible plantear que, en una disyunción exclusiva con más de dos elementos, únicamente uno de ellos puede ser verdadero.

Palabras-clave: aridad; disyunción, modelos mentales; lógica estándar; lógica estoica

\section{Introduction}

Stoic logic seems to have a problem needing to be solved. That problem refers to the disjunction. On the one hand, both ancient sources and contemporary authors appear to indicate that the disjunction was essentially exclusive for the Stoics. However, on the other hand, some ancient sources also state that the Stoics took disjunctions with more than two disjuncts into account and claimed that such disjunctions were true, as those with only two disjuncts, when only one of the disjuncts was true.

This is a problem because it appears to imply a logical mistake. Indeed, a rigorous interpretation of the exclusive disjunction does not allow assuming that, when it has, for example, three disjuncts, such a disjunction is true only if one, and only one, of their disjuncts is true. In fact, an exclusive disjunction with three disjuncts can be true if its three disjuncts are all true.

Nevertheless, my thesis is that this problem arises because we assess Stoic logic by means of standard logic, and it can easily be solved if we consider those two logics to be very different logics. In this way, I think that, if we analyze Stoic logic based on a contemporary reasoning theory, the mental models theory, it is possible to understand the real meaning of the Stoic disjunction, that that disjunction was not the disjunction of 
classical logic, and the psychological reasons that could lead the Stoics to assume a disjunction of that kind.

All of this will be shown in this paper. Nonetheless, to do that, it seems to be opportune to begin by commenting the ancient sources that appear to present us the problem. After that, it will be explained why it is often thought that what those sources indicate is a problem. And, finally, the main theses of the mental models theory on the disjunction will be exposed, and it will be accounted for how such theses enable to understand the actual sense of the Stoic disjunction and to remove the initial problem that the ancient sources seem to raise. I begin with the information provided by the sources.

\section{The disjunction in the Stoicism}

A very important point of Stoic logic is that the disjunction seems to be essentially exclusive in that logical system. Although at a certain moment the Stoics could accept an inclusive disjunction, the sources are very clear in this regard and show us that the basic disjunction in the Stoicism was the exclusive disjunction. As indicated by O'Toole and Jennings, ${ }^{3}$ such sources include passages written by authors such as Cicero, ${ }^{4}$ Gellius, ${ }^{5}$ Galen, ${ }^{6}$ Sextus Empiricus, ${ }^{7}$ and Diogenes Laërtius. ${ }^{8}$ However, as they also comment ${ }^{9}$, a number of modern authors, taking those passages into account, concluded that there was no doubt that the Stoic disjunction was mainly exclusive as well. Such authors are Bocheński, ${ }^{10}$ Kneale

3. O'Toole, R. R. \& Jennings, R. E.: "The Megarian and the Stoics" in Gabbay, M. D. \& Woods, J.: Handbook of the History of Logic, Volume I. Greek, Indian and Arabic Logic. Amsterdam: Elsevier, 2004, pp. 499-500.

4. Cicero: Topica, 14.56-7.

5. Gellius: Noctes Atticae, 16.8.

6. Galen: Institutio Logica, 5.1.

7. Sextus Empiricus: Pyrrhoniae Hypotyposes 2.191.

8. Diogenes Laërtius: Vitae Philosophorum 7.72.

9. O’Toole, R. R. \& Jennings, R. E.: op. cit., pp. 498-499.

10. Bocheński, I. M.: Ancient Formal Logic. Amsterdam: North-Holland, 1963, p. 91.

Thémata. Revista de Filosofía №54 (2016) pp.: 233-246. 
and Kneale, ${ }^{11}$ Lukasiewicz, ${ }^{12}$ Mates,${ }^{13}$ and Mueller. ${ }^{14}$ In this regard, papers such as, for example, that of López-Astorga ${ }^{15}$ can also be very illustrative.

Nonetheless, the problem is that some of the ancient sources mentioned speak about disjunctions with more than two disjuncts. The particular passages are the following:

Gellius ${ }^{16}$ says,

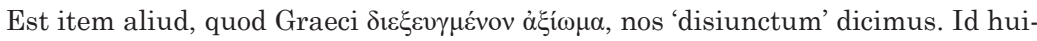
uscemodi est: 'aut malum est voluptas aut bonum aut neque bonum neque malum est'. Omnia autem, quae disiunguntur, pugnantia esse inter sese oportet, eorumque

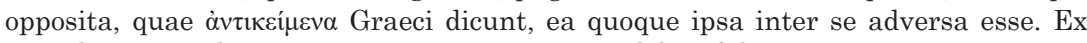
ominibus, quae disiunguntur, unum esse verum debet, falsa cetera.

That is, "there is another type named $\delta i \varepsilon \xi \varepsilon v \gamma \mu \varepsilon$ vov $\alpha \dot{\xi}\{\omega \mu \alpha$ by the Greeks, named disjunction [disiunctum] by us. It is, for example, "pleasure is good or pleasure is evil or pleasure is neither good nor evil'. But these disjuncts must be all considered to be contradictory to each other, and their contraries, which are named $\alpha v \tau$ considered to be contradictory too. Of all the disjuncts, only one should be true, and the others should be false.'

On the other hand, Galen ${ }^{17}$ states,

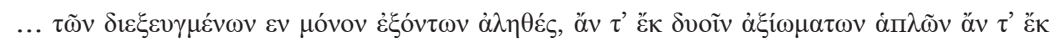

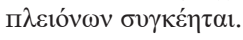

11. Kneale, W. \& Kneale, M.: The Development of Logic. Oxford: Clarendon, 1962, p. 162.

12. Lukasiewicz, J.: "On the history of the logic of propositions" in McCall, S.:

Polish Logic: 1920-1939. New York: Oxford University Press, 1967, p. 74.

13. Mates, B.: Stoic Logic. Berkeley and Los Angeles: Uni-

versity of California Press, 1953, p. 51.

14. Mueller, I.: "An introduction to Stoic logic" in Rist, J. M.: The Stoics. Berkeley: University of California Press, 1978, p. 16.

15. López-Astorga, M.: "Chrysippus' indemonstrables and mental logic" in Croatian Journal of Philosophy 15(43), 2015, p. 7.

16. Gellius: op. cit., 16.8.

17. Galen: op. cit., 5.1.

Thémata. Revista de Filosofía №54 (2016) pp.: 233-246. 
That is, '... disjunctions only have one true disjunct, whether they consist of only two propositions or of more of them.'

Finally, Sextus Empiricus ${ }^{18}$ claims,

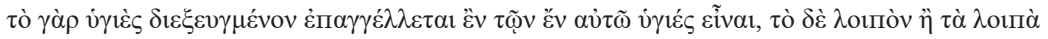

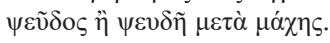

That is, '... with regard to sound disjunctions, states that one disjunct is sound, and the other disjunct or disjuncts is or are false, or false and opposed.'

Leaving aside the fact that Sextus Empiricus does not appear to

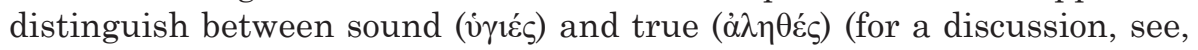
e.g., Mates ${ }^{19}$ or O'Toole and Jennings ${ }^{20}$ ), it can be said that, based on the previous passages, it is obvious that, in Stoic logic, when an exclusive disjunction had more than two disjuncts, if that disjunction was true, only one of its disjuncts could be true. And this is a problem because, in principle, an exclusive disjunction with three disjuncts can be true if its disjuncts are all true, especially if standard logic is assumed. I explain this point in details in the next section. However, maybe a very relevant point needs to be highlighted before. These differences between Stoic and standard logic come from the fact that the former is based on complex ontological and metaphysical assumptions about reality and world, including clear ideas on what can be true and false at the same time. On the other hand, as known, the latter refers to the material interpretation of the conditional (which, ultimately, can be attributed to Philo of Megara ${ }^{21}$ ) and the formal relationships existing between this last connective and the other logical operators, disjunction being, of course, among them. The particular consequences of all of this and why Stoic disjunction can be considered to cause difficulties related to arity can be noted below.

18. Sextus Empiricus: op. cit., 2.191.

19. Mates, B.: op. cit., p. 132.

20. O’Toole, R. R. \& Jennings, R. E.: op. cit., p. 477.

21. See, e.g., ibidem, p. 479. References about this issue can be found there. In particular, O'Toole and Jennings mention texts such as, for example, Sextus Empiricus: op. cit., 2.110; Mates, B.: op. cit., p. 44; Bocheński, I. M.: op. cit., p. 89. 


\section{The exclusive disjunction with three disjuncts}

It is clear that, if I state a proposition such as 'A or B but not both', I mean that there are only two possibilities: i) A is true and B is false, or ii) $\mathrm{A}$ is false and $\mathrm{B}$ is true. My asseveration admits neither both of them being true nor both of them being false. The difficulty arises when the disjunction has more than two disjuncts and, at the same time, is intended to be exclusive. In this case, the structure of the proposition could be, for example, 'either A or B or $\Gamma$ ', and the problem can be noted more easily if we use symbols such as those of standard logic and consider the general requirements of this last logic.

Let us assume that ' $\mathrm{v}$ ' stands for the exclusive disjunction. If this is so, the previous exclusive disjunction could be expressed in this way:

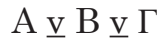

But in standard logic we can use brackets in order to separate the disjuncts. Thus, the formula could also be expressed as follows:

$$
\mathrm{A}_{\underline{\mathrm{v}}}\left(\mathrm{B}_{\underline{\mathrm{v}}} \Gamma\right)
$$

Let us suppose now that $\mathrm{A}$ is true. It this is so, $\mathrm{B} \underline{\mathrm{v}} \Gamma$ must be false. However, an exclusive disjunction such as the latter can be false in two cases:

-If both $B$ and $\Gamma$ are true.

-If both $\mathrm{B}$ and $\Gamma$ are false.

All of this means that the entire formula $\mathrm{A}_{\underline{\mathrm{v}}}\left(\mathrm{B}_{\underline{\mathrm{v}}} \Gamma\right)$ can be true in the case that the disjuncts are all true. As said, If $B$ is true and $\Gamma$ is also true, $\mathrm{B} \underline{\mathrm{v}} \Gamma$ is false. But, if $\mathrm{A}$ is true too, $\mathrm{A}_{\underline{\mathrm{v}}}\left(\mathrm{B}_{\underline{\mathrm{v}} \Gamma)}\right)$ is true as well.

This argument seems to be inconsistent with the Stoics' idea that, in an exclusive disjunction with more than two disjuncts, only one of them can be true and the others must be false. O'Toole and Jennings ${ }^{22}$ present an interesting discussion in this regard and comment on some possible solutions to the problem. In this way, they analyze an alternative form to 
express exclusive disjunctive formulae with three or more disjuncts. That form is this one:

$$
\underline{\mathrm{v}}(\mathrm{A}, \mathrm{B}, \Gamma)
$$

Thus, the inconvenience that the use of the brackets causes would disappear and it could be claimed that, for the Stoics, the real structure

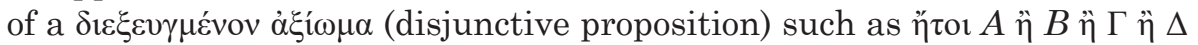

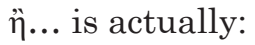

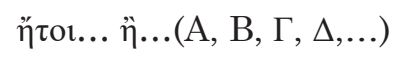

Nevertheless, regardless of this discussion and the thesis that is finally accepted by O'Toole and Jennings, I think that the mental models theory has the necessary resources to solve the problem of the disjunction in Stoic logic, and that, based on the essential theses of that theory, it is possible to offer a very simple and easy explanation of the difficulties described above. However, before showing how that explanation can be drawn from the theses of the mental models theory, it seems opportune to expose which such theses are exactly.

\section{The mental models theory and the disjunction}

The mental models theory (e.g., Johnson-Laird; ${ }^{23}$ Khemlani \& Johnson-Laird $;{ }^{24}$ Khemlani, Orenes, \& Johnson-Laird; ${ }^{25}$ Oakhill \& Garnham; ${ }^{26}$ Orenes \& Johnson-Laird ${ }^{27}$ ) is a cognitive theory claiming that human re-

23. Johnson-Laird, P. N.: How We Reason. Oxford: Oxford University Press, 2006; Johnson-Laird, P. N.: "Against logical form" in Psychologica Belgica 5(3/4), 2010, pp. 193-221; Johnson-Laird, P. N.: "Inference with mental models" in Holyoak, K. J. \& Morrison, R. G.: The Oxford Handbook of Thinking and Reasoning. New York: Oxford University Press, 2012, pp. 134-145.

24. Khemlani, S. \& Johnson-Laird, P. N.: "Disjunctive illusory inferences and how to eliminate them" in Memory \& Cognition 37(5), 2009, pp. 615-623.

25. Khemlani, S., Orenes, I., \& Johnson-Laird, P. N.: "Negation: A theory of its meaning, representation, and use" in Journal of Cognitive Psychology 24(5), 2012, pp. 541-559; Khemlani, S., Orenes, I., \& Johnson-Laird, P. N.: "The negation of conjunctions, conditionals, and disjunctions" in Acta Psychologica, 151, 2014, pp. 1-7.

26. Oakhill, J. \& Garnham, A. (Eds.): Mental Models in Cognitive Science. Essays in Honour of Phil Johnson-Laird. Hove: Psychology Press, 1996.

27. Orenes, I. \& Johnson-Laird, P. N.: "Logic, models, and paradoxical inferences" in Mind \& Language 27(4), 2012, pp. 357-377.

Thémata. Revista de Filosofía $\mathrm{N}^{\circ} 54$ (2016) pp.: 233-246. 
asoning is led by means of semantic and iconic models. The main idea is that, when faced to inferences, the human mind considers the possibilities that can be linked to each proposition in such inferences. Thus, the conclusions are derived or checked by combining those possibilities, admitting those that are consistent, and rejecting those that are inconsistent.

However, according to the theory, people do not always note all the possibilities, named 'models', corresponding to each proposition. There are models that are easy to detect, i.e., 'Mental Models', and models that are hard to identify, i.e., 'Fully Explicit Models'. The former models require little effort to be noted. Nevertheless, the latter models need a great deal of thought to be detected.

The literature on the mental models theory is huge. But, for the aims of this paper, only its account of the exclusive disjunction is relevant. In this way, it can be said that, following the theory, the Mental Models of an exclusive disjunction such as 'A or B but not both of them' are these ones:

A

B

This means that, given an exclusive disjunction, initially, individuals only note that two scenarios are possible: in one of them, only A happens, and, in the other one, only B occurs. Only subsequently, and if certain mental effort is made, they realize that those scenarios are incomplete and that the actual situations are as follows:
A
(B)

(A)

B

Where the brackets indicate that the element between them is denied.

These two last models are the Fully Explicit Models of the exclusive disjunction and, ad it can be noted, the information is more complete in them. Now, the first one not only indicates that A happens, but also that $B$ does not happen. On the other hand, the second one not only shows that B occurs, but also that A does not occur.

The proponents of the mental models theory think that this distinction (Mental Models versus Fully Explicit Models) is always important. Nonetheless, it is so especially when an exclusive disjunction has more 
than two disjuncts. Indeed, if we consider a disjunction such as, for example, 'A or B or $\Gamma$ ' and interpret it as exclusive, the Mental Models would be:

A

B $\Gamma$

However, the Fully Explicit Models would include all the possible situations for an exclusive disjunction with three disjuncts. That is:

$\begin{array}{ccc}\mathrm{A} & \mathrm{B} & \Gamma \\ \mathrm{A} & (\mathrm{B}) & \Gamma \\ (\mathrm{A}) & \mathrm{B} & (\Gamma) \\ (\mathrm{A}) & (\mathrm{B}) & \Gamma\end{array}$

Although the mental models theory does not claim that the human mind works by taking the requirements of standard logic into account, as it can be checked, these four scenarios match the situations in which, according to that logic, the exclusive disjunction is correct. Nevertheless, what is really interesting here is that it can be thought that people reason about exclusive disjunctions with more than two disjuncts in a natural way by considering only their Mental Models. Khemlani and Johnson-Laird ${ }^{28}$ proved this idea and stated that it can be predicted that, if individuals must make an inference involving an exclusive disjunction with three disjuncts, they will usually identify only its Mental Models. Really, Khemlani and Johnson-Laird resorted to different reasoning tasks, but any of them can be illustrative enough in this regard. One of them is, for example, this one:

Suppose that only one of the following assertions is true:

(1) You have the mints.

(2) You have the gumballs or the lollipops, but not both.

Also, suppose you have the mints. What, if anything, follows? Is it possible that you also have either the gumballs or the lollipops? Could you have both? ${ }^{29}$

28. Khemlani, S. \& Johnson-Laird, P. N.: op. cit., pp. 615-623.

29. Ibidem, p. 618. See also, e.g., López-Astorga, M.: "A formal

theory can explain disjunctive illusory inferences" in Círculo de Lin-

güística Aplicada a la Comunicación 60, 2014, p. 128.

Thémata. Revista de Filosofía №54 (2016) pp.: 233-246. 
It is clear that, according to standard logic, the answer would have to be that it does be possible to have, in addition to the mints, the gumballs and the lollipops. Besides, that would also be the correct response if the Fully Explicit Models were considered. Nonetheless, the answer predicted by the mental models theory, and hence by Khemlani and Johnson-Lair$\mathrm{d},{ }^{30}$ is that the participants will tend to conclude that, if the mints are had, neither the gumballs nor the lollipops can be had. The reason is obvious: as indicated, participants will only detect the Mental Models and, as explicitly mentioned by Khemlani and Johnson-Laird, ${ }^{31}$ they will only note these three scenarios as possible:

Mints

Gumballs Lollipops

That is, the scenario in which you only have the mints, a scenario in which you only have the gumballs, and a scenario in which you only have the lollipops.

That prediction was confirmed and their participants significantly tended to response as expected by them. But what is truly relevant here is that their experimental results can help solve the problem of the disjunction in Stoic logic.

\section{The stoic disjunction and the Mental Models}

In my view, the Stoic disjunction is hard to understand for us only because we tend to interpret it based on standard logic (in papers such as, e.g., that of Bobzien, ${ }^{32}$ it is also held that this later logic is not the best means to analyze the Stoic one). I think that this is the main mistake and what actually causes the Stoic disjunction to seem to be unclear. The sources commented above raise little doubt: the Stoic disjunction was ex-

30. Ibidem, pp. 615-623.

31. Ibidem, p. 618.

32. Bobzien, S.: "Stoic syllogistic" in Taylor, C. C. W.: Oxford Studies in An-

cient Philosophy. Oxford, UK: Clarendon Press, 1996, p. 134.

Thémata. Revista de Filosofía $\mathrm{N}^{\circ} 54$ (2016) pp.: 233-246. 
clusive, and it was true if only one of its disjuncts was true, even if it had more that two disjuncts.

As shown, this idea is difficult to accept if it is assessed from the rules and requirements of standard logic. However, the mental models theory offers us the key to understand it. Because it can be thought that the human mind usually only identify the Mental Models of the exclusive disjunctions with more than two disjuncts (at least this is what Khemlani \& Johnson-Laird's experiments ${ }^{33}$ demonstrate), it can be claimed that that is the natural way in which that kind of disjunction is interpreted by people. Thus, from this point of view, it can be stated that the Stoic exclusive disjunction is not the exclusive disjunction of standard logic, but the exclusive disjunction such as it is really used by individuals.

Another possibility, of course, could be to think that the Stoics simply presented a technical definition of the disjunction (see O'Toole and Jennings ${ }^{34}$ for a discussion in this regard), that, according to their definition, the disjunction was exclusive, and that, nevertheless, that definition did not match that of standard logic, but, casually, that corresponding to the Mental Models of the mental models theory. In any case, a very important point is that this later theory reveals us that it is absolutely possible to consider the disjunction as in Stoic logic, i.e., to be exclusive and, at the same time, to be true only when one, and only one, of its disjuncts is true, even if it has three disjuncts or more.

So, based on all of this, it can be said that the $\delta \varepsilon \varepsilon \xi \varepsilon v \gamma \mu \varepsilon v_{v o v} \alpha \dot{\xi}(\omega \mu \alpha$ was very different from the disjunctive proposition in standard logic. The former was essentially exclusive but the relation between its disjuncts was not the same as that required by the latter. A $\delta 1 \varepsilon \xi \varepsilon v \gamma \mu \varepsilon \dot{v} v 0 v \alpha \dot{\alpha} \xi \omega \mu \alpha$ could have, for example, three disjuncts and be expressed as follows:

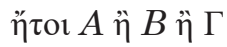

However, that does not mean that the structure of the expressions of this kind was equivalent to this one:

$$
\text { ฑ̆ॅor } A \text { ì }(B \text { ì } \Gamma)
$$

33. Khemlani, S. \& Johnson-Laird, P. N.: op. cit., pp. 615-623.

34. O’Toole, R. R. \& Jennings, R. E.: op. cit., pp. $500 f f$.

Thémata. Revista de Filosofía $\mathrm{N}^{\circ} 54$ (2016) pp.: 233-246. 
Regardless of the fact that brackets do not appear to be appropriate in Stoic logic (see O'Toole \& Jennings ${ }^{35}$ ), that only means that such expressions referred to three possible scenarios:

A

B $\Gamma$

And, given one of such expressions, only one of these scenarios could be considered to be true.

\section{Conclusions}

The literature on cognitive science shows that the mental models theory is able to account for most experimental results in reasoning tasks. Undoubtedly, this theory has open important research lines, and, of course, it can continue to open more of such lines. But something that is very relevant about this theory is that provides great doubts that reasoning and human inferential activity are actually made in accordance with modern logic. It reveals that there are other criteria for explaining and even predicting the conclusions that people often deduce from several premises. In this way, the frameworks presented in the past that appear to be wrong because they are incoherent with standard logic can be considered to be, in a certain sense, correct from the perspective of the mental models theory.

The problem can be that Greek philosophers and logicians used terms similar to those assumed by modern logic, and this fact has led to interpret the systems proposed by such philosophers and logicians from the point of view of the current logic. Nevertheless, although, as in the case of Stoic logic, connectives such as conjunction, disjunction, or the conditional were taken into account in the past, that does not mean that those connectives had the same sense or the same meaning as in modern logic (as far as this point is concerned, papers such as those of Bobzien ${ }^{36}$ or López-Astorga ${ }^{37}$ can be very enlightening). In fact, as argued in this paper for the case of the Stoic disjunction, it can be thought that there is not a

35. Ibidem, p. 501.

36. Bobzien, S.: op. cit., p. 134.

37. López-Astorga, M.: op. cit., pp. 1-15.

Thémata. Revista de Filosofía №54 (2016) pp.: 233-246. 
real correspondence between the ancient and the modern connectives, and that we should not actually require such a correspondence.

For this reason, I think that it can be very useful to resort to approaches such as the mental models theory in order to review or rewrite the history of logic. This activity can allow us to analyze whether certain errors of past logical systems were really errors or they were only a result of technical definitions or criteria other than the current ones. In any event, as shown, a point seems clear: it is not a real problem that, in Stoic logic, the disjunction was exclusive and, at the same time, its proponents claimed that it was only true when only one of its disjuncts was so, including the cases in which the number of disjuncts was more than two.

\section{References}

Bobzien, S.: "Stoic syllogistic" in Taylor, C. C. W.: Oxford Studies in Ancient Philosophy. Oxford: Clarendon Press, 1996, pp. 133-192.

Bocheński, I. M.: Ancient Formal Logic. Amsterdam: North-Holland, 1963.

Cicero: Topica.

Diogenes Laërtius: Vitae Philosophorum.

Galen: Institutio Logica.

Gellius: Noctes Atticae.

Johnson-Laird, P. N.: How We Reason. Oxford: Oxford University Press, 2006.

Johnson-Laird, P. N.: "Against logical form" in Psychologica Belgica 5(3/4), 2010, pp. 193-221.

Johnson-Laird, P. N.: "Inference with mental models" in Holyoak, K. J. \& Morrison, R. G.: The Oxford Handbook of Thinking and Reasoning. New York: Oxford University Press, 2012, pp. 134-145.

Khemlani, S. \& Johnson-Laird, P. N.: "Disjunctive illusory inferences and how to eliminate them" in Memory \& Cognition 37(5), 2009, pp. 615-623.

Khemlani, S., Orenes, I., \& Johnson-Laird, P. N.: "Negation: A theory of its meaning, representation, and use" in Journal of Cognitive Psychology 24(5), 2012, pp. 541-559.

Khemlani, S., Orenes, I., \& Johnson-Laird, P. N.: "The negation of conjunctions, conditionals, and disjunctions" in Acta Psychologica 151, 2014, pp. 1-7.

Kneale, W. \& Kneale, M.: The Development of Logic. Oxford: Clarendon, 1962. 
López-Astorga, M.: "Chrysippus' indemonstrables and mental logic" in Croatian Journal of Philosophy, 15(43), 2015, pp. 1-15.

López-Astorga, M.: "A formal theory can explain disjunctive illusory inferences" in Círculo de Lingüistica Aplicada a la Comunicación 60, 2014, pp. 122-143.

Lukasiewicz, J.: "On the history of the logic of propositions" in McCall, S.: Polish Logic: 1920-1939. New York: Oxford University Press, 1967, pp. 67-68.

Mates, B.: Stoic Logic. Berkeley and Los Angeles: University of California Press, 1953.

Mueller, I.: "An introduction to Stoic logic" in Rist, J. M.: The Stoics. Berkeley: University of California Press, 1978, pp. 1-26.

Oakhill, J. \& Garnham, A. (Eds.): Mental Models in Cognitive Science. Essays in Honour of Phil Johnson-Laird. Hove: Psychology Press, 1996.

Orenes, I. \& Johnson-Laird, P. N.: "Logic, models, and paradoxical inferences" in Mind \& Language 27(4), 2012, pp. 357-377.

O'Toole, R. R. \& Jennings, R. E.: "The Megarian and the Stoics" in Gabbay, M. D. \& Woods, J.: Handbook of the History of Logic, Volume I. Greek, Indian and Arabic Logic. Amsterdam: Elsevier, 2004, pp. 397-522. Sextus Empiricus: Pyrrhoniae Hypotyposes. 